Article

\title{
Ruminal Fermentation, Milk Production Efficiency, and Nutrient Digestibility of Lactating Dairy Cows Receiving Fresh Cassava Root and Solid Feed-Block Containing High Sulfur
}

\author{
Gamonmas Dagaew ${ }^{1}$, Anusorn Cherdthong ${ }^{1, *(\mathbb{D}}$, Metha Wanapat ${ }^{1} \mathbb{C}$, Sarong So ${ }^{1} \mathbb{C}^{-}$and Sineenart Polyorach ${ }^{2}$ \\ 1 Tropical Feed Resources Research and Development Center (TROFREC), Department of Animal Science, \\ Faculty of Agriculture, Khon Kaen University, Khon Kaen 40002, Thailand; \\ gamonmasdagaew@gmail.com (G.D.); metha@kku.ac.th (M.W.); sarong07so@gmail.com (S.S.) \\ 2 Department of Animal Production Technology and Fisheries, Faculty of Agricultural Technology, \\ King Mongkut's Institute of Technology, Bangkok 10520, Thailand; sineenart.po@kmitl.ac.th \\ * Correspondence: anusornc@kku.ac.th
}

Citation: Dagaew, G.; Cherdthong, A.; Wanapat, M.; So, S.; Polyorach, S. Ruminal Fermentation, Milk Production Efficiency, and Nutrient Digestibility of Lactating Dairy Cows Receiving Fresh Cassava Root and Solid Feed-Block Containing High Sulfur. Fermentation 2021, 7, 114. https://doi.org/10.3390/ fermentation7030114

Academic Editors: Luca Settanni and Mohamed Koubaa

Received: 8 June 2021

Accepted: 12 July 2021

Published: 14 July 2021

Publisher's Note: MDPI stays neutral with regard to jurisdictional claims in published maps and institutional affiliations.

Copyright: (c) 2021 by the authors. Licensee MDPI, Basel, Switzerland. This article is an open access article distributed under the terms and conditions of the Creative Commons Attribution (CC BY) license (https:// creativecommons.org/licenses/by/ $4.0 /)$.

\begin{abstract}
This study evaluates the effects of fresh cassava root (CR) and a solid feed-block containing sulfur (S-FB) on fermentation in the rumen, feed utilization, milk yield, and milk composition in lactating dairy cows. Four Holstein-Friesian cows with $470 \pm 50.0 \mathrm{~kg}$ body weight (BW), $10 \pm 2 \mathrm{~kg} \mathrm{day}^{-1}$ average milk yield, and $112 \pm 15$ days-in-milk were studied. A $2 \times 2$ factorial combination was arranged in a $4 \times 4$ Latin square design to evaluate the treatment-related effects. The treatments were obtained from a combination of two factors: (1) levels of CR at $10 \mathrm{~g} \mathrm{~kg}^{-1} \mathrm{BW}$ (CR-1) and $15 \mathrm{~g} \mathrm{~kg}^{-1}$ (CR-1.5) and (2) levels of sulfur supplementation in solid feed-block at $20 \mathrm{~g} \mathrm{~kg}^{-1}$ (S-FB-2) and $40 \mathrm{~g} \mathrm{~kg}^{-1}$ (S-FB-4). The results showed that CR and S-FB had no interaction effect on feed intake, digestibility, fermentation, blood metabolites, milk yield, or its composition. Feeding CR up to $15 \mathrm{~g} \mathrm{~kg}^{-1}$ of the BW significantly increased $(p<0.05)$ the milk fat concentration while it decreased $(p<0.05)$ the somatic cell count. The S-FB-4 of the sulfur significantly $(p<0.05)$ increased the acid detergent fiber when compared with the S-FB-2 of the sulfur. CR could be fed up to $15 \mathrm{~g} \mathrm{~kg}^{-1}$ of BW with S-FB containing high sulfur $\left(40 \mathrm{~g} \mathrm{~kg}^{-1}\right)$ in dairy cows without a negative impact.
\end{abstract}

Keywords: rumen fermentation; volatile fatty acid; somatic cell count; milk thiocyanate

\section{Introduction}

Fresh cassava root (CR) is high in digestible carbohydrates, mainly starch, and is considered the main energy source for ruminants. However, feeding CR to ruminants is limited in practice due to the highly toxic hydrogen cyanide (HCN) content of the roots. Sulfur has been studied and reported to reduce the cyanide toxicity [1,2]. In ruminants, $\mathrm{HCN}$ can be rapidly detoxified by the enzymes rhodanese and $\beta$-mercaptopyruvate sulfurtransferase, which are released by rumen microbes [3]. Rhodanese is a sulfurtransferase that catalyzes the conversion of HCN to thiocyanate, which is then subsequently excreted via the urine [4]. Sulfur (S) is an important mineral in ruminant diets. Various approaches to achieving sulfur utilization, to reduce HCN toxicity, have been conducted, such as adding elemental sulfur into a fermented total mixed ration (FTMR) containing CR for dairy cows $[1,5]$, adding sulfur to a concentrate of cassava hay and foliage fed to dairy cows as a roughage source [4], and adding sulfur to a pellet diet with CR supplementation [6]. Adding sulfur to a solid feed-block might be an alternative way of using sulfur to reduce HCN toxicity in a diet containing CR.

The solid feed-block is normally formulated to contain many necessary nutrients, such as minerals, vitamins, nitrogen (e.g., urea), and energy sources (e.g., molasses) [2,7,8]. Solid feed-block feeding can continuously supply nitrogen, minerals, vitamins, and energy to ruminal microbes and can ensure adequate energy supply for the animal, resulting 
in enhanced milk production in various ruminant species [2,7]. Previous studies conducted both in vitro and in vivo in beef cattle have shown that CR supplementation with a solid feed-block containing sulfur leads to enhancement of feed efficiency, digestibility, and ruminal fermentation (e.g., increased propionate (C3) and total volatile fatty acid (VFA)) [2,9]. Enhancing feed efficiency, digestibility, and ruminal fermentation may lead to an improvement in milk production. However, the effects of feeding CR and solid feed-block containing high sulfur (S-FB) on milk yield and milk composition in lactating dairy cows have never been evaluated. Based on our companion study by Cherdthong et al. [2], finding an improvement in digestibility and rumen fermentation with CR and $\mathrm{S}-\mathrm{FB}$, a hypothesis was formulated that $\mathrm{CR}$ and $\mathrm{S}-\mathrm{FB}$ should enhance milk production and its composition.

Therefore, this study aimed to evaluate the effects of fresh CR and S-FB on fermentation in the rumen, feed utilization, milk yield, and milk composition in lactating dairy cows.

\section{Materials and Methods}

\subsection{Ethical Procedure}

The study was conducted under approval procedure no. ACUC-KKU 45/2560 of Animal Ethics and Care issued by Khon Kaen University (Date: 15 June 2017).

\subsection{Animals, Diets, and Experimental Design}

The study was conducted at the farm animal research station of the Department of Animal Science, Khon Kaen University. Due to limited research station resources and availability, only a small number of cows were used. However, the study was conducted with care and control to minimize any incidental errors originating from humans, animals, or the environment. Four Holstein-Friesian cows with $470 \pm 50.0 \mathrm{~kg}$ body weight $(\mathrm{BW})$, $10 \pm 2 \mathrm{~kg} \mathrm{day}^{-1}$ average milk yield, and $112 \pm 15$ days-in-milk were studied. A $2 \times 2$ factorial combination was arranged in a $4 \times 4$ Latin square design to evaluate the treatmentrelated effects. The treatments were obtained from a combination of two factors: (1) levels of $\mathrm{CR}$ at $10 \mathrm{~g} \mathrm{~kg}^{-1} \mathrm{BW}(\mathrm{CR}-1)$ and $15 \mathrm{~g} \mathrm{~kg}^{-1}$ (CR-1.5), and (2) levels of sulfur supplementation in solid feed-block at $20 \mathrm{~g} \mathrm{~kg}^{-1}$ (S-FB-2) and $40 \mathrm{~g} \mathrm{~kg}^{-1}$ (S-FB-4). The concentrate was fed to the cows at a 2:1 ratio ( $2 \mathrm{~kg}$ concentrate per $1 \mathrm{~kg}$ of milk yield) at $7 \mathrm{am}$ and $4 \mathrm{pm}$. The cows were fed rice straw (RS) ad libitum daily with $100 \mathrm{~g} \mathrm{~kg}^{-1}$ refusal of the total offered amount of RS. The CR (Manihot esculenta Kasetsart 50) was purchased from a local farmer located in Khon Kaen province, Thailand. The CR was washed to remove soil and chopped into 3 to $5 \mathrm{~mm}$ sized pieces before being offered to cows at their respective levels. The concentrate and CR were fed twice daily to the cows at 7 am and 4 pm simultaneously, and RS was fed after the cows finished the concentrate and CR. The S-FBs containing $20 \mathrm{~g}$ and $40 \mathrm{~g}$ sulfur were formulated as described by Cherdthong et al. [2]. The ingredients and their proportions are shown in Table 1. All ingredients were well-mixed and put into a hydraulic compression machine (Mineral Salt Block Hydraulic Press, Zhengzhou Rephale Machinery Company, Henan, China) for 3-min to produce $1 \mathrm{~kg}$ of S-FB based on the fresh weight. The S-FB were sun-dried for three days to minimize the moisture content and then stored in a clean and dry place for use in this study. The cows were placed in individual pens $(5 \times 5 \mathrm{~m})$ equipped with a cement well containing clean water; during the study, the well was cleaned daily and replenished with new and clean water. The S-FB was offered to the cows by hanging the block in individual pens and allowing the cows to access the S-FB ad libitum. The concentrate ingredients and chemical compositions of the concentrate, RS, $\mathrm{S}-\mathrm{FB}$, and $\mathrm{CR}$, in addition to the $\mathrm{HCN}$ content of $\mathrm{CR}$, are recorded in Table 1. The cows were weighed at the start of the experiment, and at the end of a period before starting a new period, the cows were weighed to adjust their dry matter intake (DMI). 
Table 1. Ingredients and chemical composition of concentrate, solid feed-block, fresh cassava root $(\mathrm{CR})$, and rice straw (RS).

\begin{tabular}{|c|c|c|c|c|c|}
\hline Items & Concentrate & S-FB-2 & S-FB-4 & CR & RS \\
\hline \multicolumn{6}{|c|}{ Ingredient Proportions, $\mathrm{g} \mathrm{kg}^{-1} \mathrm{DM}$} \\
\hline Corn & 70 & - & - & & \\
\hline Soybean pulp & 40 & - & - & & \\
\hline Cassava ship & 450 & - & - & & \\
\hline Rice bran & 50 & 300 & 300 & & \\
\hline Palm cannel meal & 95 & - & - & & \\
\hline Soybean meal & 200 & - & - & & \\
\hline Molasses & 30 & 420 & 400 & & \\
\hline Urea & 25 & 100 & 100 & & \\
\hline Di-calcium & 10 & - & - & & \\
\hline Vitamin & 5 & - & - & & \\
\hline Semen & - & 110 & 110 & & \\
\hline Sulfur & - & 20 & 40 & & \\
\hline Premixed & - & 20 & 20 & & \\
\hline Salt & 5 & 10 & 10 & & \\
\hline Tallow & - & 20 & 20 & & \\
\hline \multicolumn{6}{|c|}{ Chemical Composition } \\
\hline $\mathrm{DM}, \mathrm{g} \mathrm{kg}^{-1}$ & 896 & 791 & 763 & 385 & 849 \\
\hline $\mathrm{OM}, \mathrm{g} \mathrm{kg}^{-1} \mathrm{DM}$ & 953 & 900 & 901 & 986 & 911 \\
\hline$C P, \mathrm{~g} \mathrm{~kg}^{-1} \mathrm{DM}$ & 167 & 305 & 302 & 23 & 26 \\
\hline $\mathrm{NDF}, \mathrm{g} \mathrm{kg}^{-1} \mathrm{DM}$ & 276 & 189 & 227 & 531 & 854 \\
\hline $\mathrm{ADF}, \mathrm{g} \mathrm{kg}^{-1} \mathrm{DM}$ & 118 & 100.1 & 100.3 & 312 & 476 \\
\hline TDN, $\mathrm{g} \mathrm{kg}^{-1} \mathrm{DM}$ & 791 & 820 & 815 & 825 & 444 \\
\hline $\mathrm{HCN}, \mathrm{mg} / \mathrm{kg}$ & - & - & - & 103.5 & - \\
\hline NEv, Mcal kg ${ }^{-1} \mathrm{DM}^{\dagger}$ & 1.89 & 2.01 & 1.98 & 1.75 & 0.19 \\
\hline
\end{tabular}

S-FB-2 = solid feed-block containing high sulfur of $20 \mathrm{~g} \mathrm{~kg}^{-1}$, S-FB-4 = solid feed-block containing high sulfur of $40 \mathrm{~g} \mathrm{~kg}^{-1}, \mathrm{DM}=$ dry matter, $\mathrm{OM}=$ organic matter, $\mathrm{CP}=$ crude protein, $\mathrm{NDF}=$ neutral detergent fiber, $\mathrm{ADF}=$ acid detergent fiber, $\mathrm{TDN}=$ total digestible nutrient, $\mathrm{HCN}=$ hydrogen cyanide. $\mathrm{NEv}=$ net energy value ${ }^{\dagger} \mathrm{NEv}$ $(\mathrm{Mcal} / \mathrm{kg} \mathrm{DM})=(0.01 \times(\% \mathrm{TDN}) \times[2.86-(35.5 /(100-\% \mathrm{NDF})] /(2.2 \times 0.45)[10]$. - ingredients were not used in the formulations.

\subsection{Sample Collection and Measurements}

Four 21-day periods consisting of two parts were conducted in this study; the first 14 days were used for dietary treatment adaptation and the last seven days were used for sample collection.

During the last seven days of each period, feed (RS, concentrate, and CR), refusal, and feces samples were collected daily and divided into two equal parts. The first half of the samples were analyzed daily for their DM content, while the other half of the samples were grouped by cows and periods and stored at $-20^{\circ} \mathrm{C}$ for analysis for their chemical composition. The feces were collected using the spot sampling technique at $50 \mathrm{~g} \mathrm{~kg}^{-1}$ total fresh weight. To analyze the chemical composition of the feed and refusal, the frozen feed, refusal, and fecal samples were thawed and oven-dried at $60^{\circ} \mathrm{C}$ for $72 \mathrm{~h}$. Then, the feed, refusal, and feces samples were ground through a 1-mm screen and analyzed for their DM, ash, and crude protein (CP) according to Association of Official Agricultural Chemists (AOAC) [11], and neutral detergent fiber (NDF) and acid detergent fiber (ADF) according to Van Soest et al. [12]. The hydrocyanic acid (HCN) concentrations in CR were analyzed according to the method cited by Supapong and Cherdthong [1] using UV/Vis spectrophotometry. The HCN was calculated using the following: total cyanide content $(\mathrm{mg} / \mathrm{kg})=396 \times$ absorbance reading. Acid insoluble ash (AIA) was used as an indicator to estimate the apparent digestibility [13].

On day 21 of each period, rumen fluid and blood samples were collected at 0 and $4 \mathrm{~h}$ post-feeding. Approximately $100 \mathrm{~mL}$ of rumen fluid was collected via a stomach tube attached to a vacuum machine. The $\mathrm{pH}$ and temperature of the rumen fluid samples were measured immediately using a glass electrode $\mathrm{pH}$ meter (HANNA Instru- 
ment (HI) 8424 microcomputer, Singapore). Rumen fluid samples were then filtered through a four-layer cheesecloth, kept in $1 \mathrm{M}$ of sulfuric acid at a 1:9 ratio (5 $\mathrm{mL}$ of sulfuric acid and $45 \mathrm{~mL}$ of rumen fluid), and stored at $-20{ }^{\circ} \mathrm{C}$ before being used for analysis. The rumen fluid samples were used to analyze the ammonia nitrogen $\left(\mathrm{NH}_{3}-\mathrm{N}\right)$ concentration and VFA molar portions (acetate-C2, C3, and butyrate-C4). The $\mathrm{NH}_{3}-\mathrm{N}$ concentration was analyzed according to AOAC [14]. The VFA was analyzed using highperformance liquid chromatography (HPLC; water 600 UV detector, Millipore). VFA profiles were used for methane $\left(\mathrm{CH}_{4}\right)$ prediction according to the equation of Moss et al. [15] $\left(\mathrm{CH}_{4}=(0.45 \times\right.$ acetic acid $)-(0.275 \times$ propionic acid $)+(0.40 \times$ butyric acid $\left.)\right)$. The remaining rumen fluid samples were kept in $3.3 \mathrm{M}$ formalin at a 1:9 ratio $(1 \mathrm{~mL}$ formalin and $9 \mathrm{~mL}$ rumen fluid) and stored at $10{ }^{\circ} \mathrm{C}$ in a refrigerator to later count the bacteria, protozoa, and fungi according to Galyean [16]. Twelve milliliters of blood samples were collected from a jugular vein and divided into two equal portions. The first $6 \mathrm{~mL}$ of the blood samples were kept in test tubes containing Ethylenediaminetetraacetic acid (EDTA) and used to analyze the blood urea nitrogen (BUN) concentration according to Crocker [17], and the other $6 \mathrm{~mL}$ of the blood samples was centrifuged at $1000 \times \mathrm{g}$ immediately to collect the serum samples. The serum samples were used to analyze alanine aminotransferase (ALT), aspartate aminotransferase (AST), triiodothyronine (T3), and thyroxine (T4) using automated clinical chemistry analyzers (Vitallab Flexor E, Dieren, Netherland). Blood thiocyanate $\left(\mathrm{SCN}^{-}\right)$ was analyzed according to the method described by Cherdthong et al. [2].

During the last seven days of each period, $100 \mathrm{~mL}$ of milk was collected daily (60 mL at the morning milking at $5 \mathrm{am}$ and $40 \mathrm{~mL}$ at the afternoon milking at $4 \mathrm{pm}$ ). The milk samples were prevented from spoilage by adding potassium dichromate at $0.2 \mathrm{~g}$ per $100 \mathrm{~mL}$ of milk sample. The milk samples were analyzed for fat, protein, lactose, and solids-not-fat using Milkoscan104 (Foss Electric, Hillerod, Denmark). Somatic cell counts (SCC) were analyzed using the Fossomatic 5000 Basic (Foss, Hillerod, Denmark). The thiocyanate partition in milk $\left(\mathrm{SCN}^{-}\right)$was analyzed according to Jacob et al. [18]. Fat-corrected milk (FCM) was calculated using the equation: $3.5 \% \mathrm{FCM}=0.35 \times$ milk yield $(\mathrm{kg})+15$ fat yield $(\mathrm{kg})$.

\subsection{Statistical Analysis}

All data were subjected to ANOVA according to a $2 \times 2$ factorial arrangement in a $4 \times 4$ Latin square design using the general linear models (GLM) procedures of SAS. The analysis model is as follows Equation (1):

$$
Y_{i j k l}=\mu+C_{i}+S_{j}+C S_{i j}+A_{k}+P_{1}+\varepsilon_{i j k l}
$$

where $Y_{i j k}$ is the observation, $\mu$ is the overall mean, $C_{i}$ is the effect of $C R$ at $10 \mathrm{~g} \mathrm{~kg}^{-1} \mathrm{BW}$ and $15 \mathrm{~g} \mathrm{~kg}^{-1}, \mathrm{~S}_{\mathrm{j}}$ is the effect of sulfur addition to a solid feed-block at $20 \mathrm{~g} \mathrm{~kg}^{-1}$ and $40 \mathrm{~g} \mathrm{~kg}^{-1}, \mathrm{CS}_{\mathrm{ij}}$ is the interaction effect between CR and sulfur levels in a solid feed-block, $A_{k}$ is the effect from the animal, $P_{1}$ is the effect from the period, and $\varepsilon_{i j k l}$ is the residual effect. The means of treatment were statistically compared using Tukey's test [19] and significant treatment means were accepted at $p<0.05$.

\section{Results and Discussion}

\subsection{Chemical Composition of Feeds}

The concentrate was formulated to contain $167 \mathrm{~g} \mathrm{~kg}^{-1} \mathrm{DM}$ of CP to ensure the nutrient requirement for cows according to National Research Council (NRC) [20] and a cassava chip was used as an energy source. In addition to the energy source, $C R$ feeding served as an additional energy supply. The S-FB contained approximately $300 \mathrm{~g} \mathrm{~kg}^{-1} \mathrm{DM}$ of CP, which mainly consisted of urea as the nitrogen source for microbial protein synthesis [8]. The HCN concentration in CR was lower than that previously reported by Wanapat and Kang [21] (85-114 $\mathrm{mg} \mathrm{kg}^{-1}$ fresh basis). The variation in HCN concentration mainly depends on breed varieties and the growth environment [2]. 


\subsection{Effect on Intake and Digestibility}

The concentrate, RS, S-FB, sulfur, CR, HCN, and total DM intake are shown in Table 2. An interactive effect between $C R$ and S-FB for intake was not observed. The S-FB-2 and S-FB-4 were no different for the intake of RS, concentrate, S-FB, sulfur, CR, HCN, or total DM (Table 2). The sulfur intake was not over the limit recommended by NRC [20], with a minimum $1.5 \mathrm{~g} \mathrm{~kg}^{-1}$ and maximum $5 \mathrm{~g} \mathrm{~kg}^{-1} \mathrm{DM}$ intake requirement in beef cattle. The intake of sulfur ranged from 0.01 to $0.02 \mathrm{~kg}$ day $^{-1}$, equaling $0.06 \%$ to $0.13 \%$ of total DM intake. Similarly, Supapong et al. [5] reported that sulfur supplementation at 10 and $20 \mathrm{~g} \mathrm{~kg}^{-1} \mathrm{DM}$ added to the FTMR for dairy cows did not influence their feed intake. In addition, Promkot and Wanapat [4] found that supplemented elemental sulfur at 1.5 and $4 \mathrm{~g} \mathrm{~kg}^{-1}$ of dietary DM did not affect feed intake. In beef cattle, feed-blocks containing sulfur at 20 and $40 \mathrm{~g} \mathrm{~kg}^{-1}$ did not alter the feed intake [2]. The intake of concentrate, RS, S-FB, CR, sulfur, and total DM was not observed between CR-1 and CR-1.5 (Table 2). Increasing the $\mathrm{CR}$ supplementation caused a significant increase in $\mathrm{HCN}$ intake. This finding could be due to an increase in the CR feeding amount from 10 to $15 \mathrm{~g} \mathrm{~kg}^{-1} \mathrm{BW}$. The HCN intake was $600.35 \mathrm{mg} \mathrm{kg}^{-1}$ and $614.55 \mathrm{mg} \mathrm{kg}^{-1}$ for CR-1 and CR-1.5 treatment, respectively. Similarly, after Cherdthong et al. [2] fed CR at 10 and $15 \mathrm{~g} \mathrm{~kg}^{-1} \mathrm{BW}$ to beef cattle, a significant increase in CR intake was noted. Promkot and Wanapat [4] reported that the $\mathrm{HCN}$ intake in dairy cows was significantly observed when cassava (hay and foliage) was fed at $100 \mathrm{~g} \mathrm{~kg}^{-1} \mathrm{DM}$, with HCN intakes of $1128.4 \mathrm{mg} \mathrm{day}^{-1}$ and $103.25 \mathrm{mg} \mathrm{day}^{-1}$ for cassava foliage and cassava hay feeding, respectively.

Table 2. Effect of cassava root (CR) and solid feed-block containing high sulfur (S-FB) on feed intake, nutrient intake, and nutrient digestibility in lactating dairy cows.

\begin{tabular}{|c|c|c|c|c|c|c|c|c|}
\hline \multirow{2}{*}{ Items } & \multicolumn{2}{|c|}{ CR-1 } & \multicolumn{2}{|c|}{ CR-1.5 } & \multirow{2}{*}{ SEM } & \multicolumn{3}{|c|}{$p$-Value } \\
\hline & S-FB-2 & S-FB-4 & S-FB-2 & S-FB-4 & & CR & S-FB & $C R^{*} S-F B$ \\
\hline Rice straw, kg day ${ }^{-1}$ & 4.0 & 4.0 & 3.8 & 3.7 & 0.33 & 0.51 & 0.88 & 0.96 \\
\hline Rice straw, $\mathrm{g} \mathrm{kg}^{-1} \mathrm{BW}^{0.75}$ & 39.9 & 39.8 & 37.6 & 38.2 & 3.59 & 0.59 & 0.96 & 0.95 \\
\hline Concentrate, $\mathrm{kg}$ day $^{-1}$ & 5.8 & 6.8 & 7.3 & 6.3 & 0.56 & 0.39 & 1.00 & 0.09 \\
\hline Concentrate, $\mathrm{g} \mathrm{kg}^{-1} \mathrm{BW}^{0.75}$ & 64.5 & 68.8 & 64.8 & 66.0 & 6.76 & 0.96 & 0.87 & 0.99 \\
\hline $\mathrm{CR}, \mathrm{kg}$ day $^{-1}$ & 5.3 & 5.6 & 7.8 & 7.7 & 0.72 & 0.84 & 1.00 & 0.96 \\
\hline $\mathrm{S}-\mathrm{FB}, \mathrm{kg}$ day $^{-1}$ & 0.6 & 0.5 & 0.6 & 0.5 & 0.10 & 0.76 & 0.13 & 0.89 \\
\hline Sulfur, kg day ${ }^{-1}$ & 0.02 & 0.02 & 0.02 & 0.02 & 0.004 & 0.89 & 0.45 & 0.85 \\
\hline $\mathrm{HCN}, \mathrm{mg} \mathrm{day}^{-1}$ & 563.4 & 559.4 & 637.3 & 669.7 & 75.35 & 0.01 & 0.75 & 0.87 \\
\hline Total intake, \%BW & 3.2 & 3.3 & 3.6 & 3.6 & 0.19 & 0.92 & 0.79 & 0.67 \\
\hline Total intake, $\mathrm{kg}$ day $^{-1}$ & 15.2 & 15.3 & 16.0 & 16.5 & 0.90 & 0.67 & 0.19 & 0.17 \\
\hline \multicolumn{9}{|l|}{ Nutrient intake, $\mathrm{kg}$ day $^{-1}$} \\
\hline $\mathrm{OM}$ & 13.3 & 13.3 & 14.8 & 14.5 & 0.76 & 0.21 & 0.75 & 0.64 \\
\hline $\mathrm{CP}$ & 3.3 & 3.3 & 3.6 & 3.8 & 0.23 & 0.46 & 0.83 & 0.94 \\
\hline NDF & 5.3 & 5.2 & 6.3 & 5.6 & 0.57 & 0.85 & 0.72 & 0.60 \\
\hline ADF & 3.4 & 3.5 & 4.3 & 3.9 & 0.44 & 0.63 & 0.81 & 0.86 \\
\hline \multicolumn{9}{|c|}{ Nutrient digestibility, $\mathrm{g} \mathrm{kg}^{-1}$} \\
\hline $\mathrm{DM}$ & 739 & 743 & 733 & 755 & 0.76 & 0.21 & 0.46 & 0.73 \\
\hline $\mathrm{OM}$ & 872 & 873 & 871 & 874 & 0.34 & 0.25 & 0.45 & 0.93 \\
\hline $\mathrm{CP}$ & 795 & 782 & 778 & 790 & 0.77 & 0.29 & 0.56 & 0.89 \\
\hline NDF & 694 & 630 & 668 & 702 & 3.58 & 0.37 & 0.71 & 0.88 \\
\hline ADF & 545 & 559 & 543 & 570 & 0.87 & 0.29 & 0.03 & 0.47 \\
\hline
\end{tabular}

CR-1 and CR-1.5 = fed CR at 10 and $15 \mathrm{~g} \mathrm{~kg}^{-1}$ BW, S-FB-2 and S-FB-4 = solid feed-block containing high sulfur at 20 and $40 \mathrm{~g} \mathrm{~kg}{ }^{-1}$, $\mathrm{BW}^{0.75}=$ metabolic body weight, $\mathrm{HCN}=$ hydrogen cyanide, $\mathrm{DM}=$ dry matter, $\mathrm{OM}=$ organic matter, $\mathrm{CP}=$ crude protein, $\mathrm{NDF}=$ neutral detergent fiber, $\mathrm{ADF}=$ acid detergent fiber, $\mathrm{SEM}=$ standard error of mean, $\mathrm{CR}{ }^{*} \mathrm{~S}-\mathrm{FB}=$ interaction between $\mathrm{CR}$ and $\mathrm{S}-\mathrm{FB}$.

The nutrient intake and digestibility are presented in Table 2. An interactive effect between CR and S-FB for nutrient intake was not observed. S-FB-2 and S-FB-4 did not influence nutrient intake. Uwituze et al. [22] found that sulfur supplementation at 4.2 and $6.5 \mathrm{~g} \mathrm{~kg}^{-1}$ of dietary DM in crossbred steers did not affect nutrient intake. Supapong and Cherdthong [1] added 10 and $20 \mathrm{~g} \mathrm{~kg}^{-1}$ into the FTMR for dairy cows and no effects on 
nutrient intake were revealed. CR-1 and CR-1.5 did not affect the nutrient intake (Table 3). This finding might be due to there being no negative effects of CR on feed intake, as seen in Table 2. The HCN intakes were $600.35 \mathrm{mg} \mathrm{kg}^{-1}$ and $614.55 \mathrm{mg} \mathrm{kg}^{-1}$ when fed at $10 \mathrm{~g} \mathrm{~kg}^{-1}$ and $15 \mathrm{~g} \mathrm{~kg}^{-1} \mathrm{BW}$ of CR, respectively, which were quite high, but toxic symptoms were not observed throughout the trial. No toxic symptoms were observed even when the animals received a high amount of HCN. This finding could be explained by the high sulfur content in the solid feed-block, which would have stimulated increase rhodanese enzyme activity to break down $\mathrm{HCN}$ into nontoxic $\mathrm{SCN}^{-}$in the liver (Table 6). An interactive effect between CR and S-FB on nutrient digestibility was not observed (Table 3). CR-1 and CR-1.5 did not influence nutrient digestibility, a finding that suggests that feeding CR at $15 \mathrm{~g} \mathrm{~kg}^{-1}$ of BW had no negative effects on the animal. Dagaew et al. [9] found that increasing the CR in the RS ratio resulted in a significant increase in the in vitro digestibility of DM, NDF, and ADF. The authors addressed this finding as being due to the increase in the digestible DM of CR in the substrate. S-FB-4 caused a significant increase in ADF digestibility when compared with S-FB-2. The rumen consists of a huge population of bacteria, fungi, and protozoa; some bacteria are anaerobic sulfate-reducing bacteria that use sulfur as a substrate for sulfate production and reduction into hydrogen sulfide $\left(\mathrm{H}_{2} \mathrm{~S}\right)$ in the rumen [1,2]. However, $\mathrm{H}_{2} \mathrm{~S}$ production was favored at a ruminal $\mathrm{pH}$ of 6.5 [22-24]. As shown in Table 4, the $\mathrm{pH}$ ranged from 6.6 to 6.8 , a finding that suggests that this range of $\mathrm{pH}$ was not a favorable condition for $\mathrm{H}_{2} \mathrm{~S}$ production. Therefore, the excess sulfate production was used by other anaerobic rumen fungi and fibrolytic rumen bacteria to increase their populations by incorporating sulfur from sulfate through direct metabolism or via an indirect pathway via the sulfide pool [25]. Slyter et al. [26] revealed that sulfur could cause an increase in the activity of cellulolytic bacteria, a process that might enhance fiber degradability [27]. Dagaew et al. [9] found that a feed-block containing sulfur at 20 and $40 \mathrm{~g} \mathrm{~kg}^{-1}$ significantly affected only the in vitro DM digestibility. Cherdthong et al. [2] fed a sulfur-containing feed-block at 20 and $40 \mathrm{~g} \mathrm{~kg}^{-1}$ to beef cattle; this process caused a significant effect on the $\mathrm{DM}$ and $\mathrm{OM}$ digestibility but not the $\mathrm{CP}, \mathrm{NDF}$, or ADF digestibility. This finding might be due to the low fungal population in that study when compared with this study. In dairy cows, Promkot and Wanapat [4] found that sulfur supplementation at 1.5 and $4 \mathrm{~g} \mathrm{~kg}^{-1}$ DM had a significant influence on DM digestibility. The variation among these findings is not understood, although it might be due to variations in the selected sulfur form, type of animal breed, and dietary composition.

\subsection{Characteristics of Rumen Ecology and Microorganism}

The ruminal $\mathrm{pH}$, temperature, $\mathrm{NH}_{3}-\mathrm{N}$, and microbial population are presented in Table 3. Interactive effects between $\mathrm{CR}$ and $\mathrm{S}-\mathrm{FB}$ on $\mathrm{pH}$, temperature, $\mathrm{NH}_{3}-\mathrm{N}$ concentration, and bacteria and protozoal populations were not observed. S-FB-2 and S-FB-4 did not affect the $\mathrm{pH}$, temperature, $\mathrm{NH}_{3}-\mathrm{N}$ concentration, or microbial population (Table 4). The mean rumen $\mathrm{pH}$ ranged from 6.6 to 6.8 , which was in the optimal range for microbial activity. Cherdthong et al. [2] similarly found that $\mathrm{pH}$, temperature, $\mathrm{NH}_{3}-\mathrm{N}$, and protozoal population significantly increased when beef cattle were fed CR and feed-block containing $40 \mathrm{~g} \mathrm{~kg}^{-1}$ sulfur in the feed-block. Promkot and Wanapat [4] found an increase in the bacterial population with sulfur supplementation at 1.5 and $4 \mathrm{~g} \mathrm{~kg}^{-1}$ of DM in dairy cows fed diets containing cassava hay and foliage. The lack of effect of sulfur on the bacterial population in this study was not clear, although the bacterial population was $33.71 \%$ greater than the findings of Cherdthong et al. [2] and $60.04 \%$ greater than in the report by Promkot and Wanapat [4]. Cherdthong et al. [2] stated that sulfur is essential for microbial growth in the rumen and for microbial metabolism. Sulfur found in amino acids (e.g., methionine and cysteine) is used for microbial growth. CR feeding did not affect the $\mathrm{pH}$, temperature, $\mathrm{NH}_{3}-\mathrm{N}$, or microbial population (Table 4). This finding could mean that the interval difference between 10 and $15 \mathrm{~g} \mathrm{~kg}^{-1}$ of $\mathrm{CR}$ was too small to produce a ruminal $\mathrm{pH}$ change. In addition, $\mathrm{RS}$ contains high indigestible fiber and was fed ad libitum; the indigestible fiber might act as a buffering agent for maintaining $\mathrm{pH}$ in the 
rumen. This result agrees with the results of Cherdthong et al. [2], who fed CR and a feed-block containing sulfur to beef cattle, and Promkot and Wanapat [4], who fed cassava hay and foliage and sulfur to dairy cows.

Table 3. Effect of fresh cassava root (CR) and a solid feed-block containing high sulfur (S-FB) on rumen ecology, microorganism, and fermentation.

\begin{tabular}{|c|c|c|c|c|c|c|c|c|}
\hline \multirow{2}{*}{ Item } & \multicolumn{2}{|c|}{ CR-1 } & \multicolumn{2}{|c|}{ CR-1.5 } & \multirow{2}{*}{ SEM } & \multicolumn{3}{|c|}{$p$-Value } \\
\hline & S-FB-2 & S-FB-4 & S-FB-2 & S-FB-4 & & CR & S-FB & $C R^{*} S-F B$ \\
\hline \multicolumn{9}{|c|}{ Ruminal $\mathrm{pH}$} \\
\hline 0-h post-feeding & 6.9 & 6.9 & 6.8 & 6.9 & 0.18 & 0.92 & 0.66 & 0.67 \\
\hline 4-h post-feeding & 6.6 & 6.5 & 6.5 & 6.6 & 0.23 & 0.85 & 0.63 & 0.89 \\
\hline Mean & 6.8 & 6.7 & 6.6 & 6.8 & 0.19 & 0.14 & 0.38 & 0.52 \\
\hline \multicolumn{9}{|c|}{ Ruminal Temperature, ${ }^{\circ} \mathrm{C}$} \\
\hline 0-h post-feeding & 38.8 & 39.0 & 38.4 & 38.7 & 0.19 & 0.14 & 0.38 & 0.52 \\
\hline 4-h post-feeding & 39.2 & 39.1 & 38.4 & 38.9 & 0.84 & 0.07 & 0.29 & 0.25 \\
\hline Mean & 39.2 & 39.1 & 38.4 & 38.9 & 0.18 & 0.13 & 0.46 & 0.35 \\
\hline \multicolumn{9}{|c|}{ Ammonia-Nitrogen, $\mathrm{mg} \mathrm{dL}^{-1}$} \\
\hline 0 -h post-feeding & 14.5 & 16.2 & 14.7 & 16.7 & 1.46 & 0.27 & 0.77 & 0.82 \\
\hline 4-h post-feeding & 15.3 & 15.7 & 15.9 & 16.2 & 0.79 & 0.48 & 0.92 & 0.72 \\
\hline Mean & 14.9 & 15.9 & 15.3 & 16.4 & 0.61 & 0.66 & 0.19 & 0.82 \\
\hline \multicolumn{9}{|c|}{ Rumen Microbes, cells $\mathrm{mL}^{-1}$} \\
\hline \multicolumn{9}{|l|}{ Bacteria, $\times 10^{11}$} \\
\hline 0 -h post-feeding & 4.2 & 4.5 & 4.3 & 4.8 & 0.72 & 6.14 & 0.86 & 0.86 \\
\hline 4-h post-feeding & 4.7 & 5.0 & 4.8 & 5.3 & 0.73 & 0.86 & 0.62 & 0.86 \\
\hline Mean & 4.5 & 4.6 & 4.7 & 4.8 & 0.68 & 0.85 & 0.72 & 1.00 \\
\hline \multicolumn{9}{|l|}{ Protozoa $\times 10^{7}$} \\
\hline 0-h post-feeding & 1.1 & 1.2 & 1.1 & 1.2 & 0.87 & 0.88 & 0.88 & 0.33 \\
\hline 4-h post-feeding & 1.2 & 1.3 & 1.3 & 1.4 & 0.94 & 0.89 & 0.69 & 0.69 \\
\hline Mean & 1.1 & 1.1 & 1.2 & 1.2 & 1.10 & 0.50 & 0.73 & 0.73 \\
\hline \multicolumn{9}{|l|}{ Fungi $\times 10^{6}$} \\
\hline 0-h post-feeding & 0.2 & 0.3 & 0.2 & 0.3 & 0.62 & 0.84 & 0.55 & 0.55 \\
\hline 4-h post-feeding & 0.2 & 0.2 & 0.2 & 0.3 & 0.38 & 0.52 & 0.52 & 0.52 \\
\hline Mean & 0.2 & 0.3 & 0.2 & 0.3 & 0.37 & 0.33 & 0.51 & 0.74 \\
\hline
\end{tabular}

CR-1 and CR-1.5 = fed CR at 10 and $15 \mathrm{~g} \mathrm{~kg}^{-1}$ BW, S-FB-2 and S-FB-4 = solid feed-block containing high sulfur at 20 and $40 \mathrm{~g}$ kg ${ }^{-1}$ $\mathrm{SEM}=$ standard error of mean, $\mathrm{CR} * \mathrm{~S}-\mathrm{FB}=$ interaction effect between $\mathrm{CR}$ and $\mathrm{S}-\mathrm{FB}$.

\subsection{Volatile Fatty Acid (VFA) and Methane Estimation}

Table 4 shows the effects of $\mathrm{CR}$ and S-FB on VFA and $\mathrm{CH}_{4}$ production in lactating dairy cows. Interactive effects between CR and S-FB on the total VFA, molar portions of VFA, and $\mathrm{CH}_{4}$ estimations were not observed. CR-1 and CR-1.5 did not influence the total VFA or the $\mathrm{C} 2, \mathrm{C} 3, \mathrm{C} 4$, or $\mathrm{CH}_{4}$ estimations (Table 5). This finding could be attributed to the small difference in the interval between 10 and $15 \mathrm{~g} \mathrm{~kg}^{-1}$ of the CR to shift the rumen fermentation. The C 3 concentrations between CR-1 and CR-1.5 were 22 mole/100 mole and 23.5 mole/100 mole. In addition, it is possible that the CR and DM intakes and nutrient digestibility were not observed with 10 and $15 \mathrm{~g} \mathrm{~kg}^{-1} \mathrm{BW}$ of CR. This result is similar to that of the study of Promkot and Wanapat [4], who evaluated cassava hay and foliage as roughage sources in the diets of dairy cows. Cherdthong et al. [2] found a significant increase in C 3 concentration with CR 10 and $15 \mathrm{~g} \mathrm{~kg}^{-1}$ BW in beef cattle, which could have been due to a significant increase in the CR and DM intake when the CR increased as reported by the authors. S-FB-2 and S-FB-4 produced no effects on the total VFA or $\mathrm{C} 2, \mathrm{C} 3, \mathrm{C} 4$, or $\mathrm{CH}_{4}$ estimations (Table 5). The average $\mathrm{C} 3$ concentrations between S-FB-2 and S-FB-4 were 22.55 mole/100 mole and 22.95 mole/100 mole. This finding might be due to a lack of influence of S-FB on the CR and DM intakes and the digestibility of DM and OM. This result was similar to the results, both in vitro and in vivo, of the previous study by Cherdthong et al. [2], who fed a feed-block containing sulfur at 20 and $40 \mathrm{~g} \mathrm{~kg}^{-1}$ to beef cattle, as well as Promkot et al. [3], who evaluated reducing sulfur at 2, 5, and 
$10 \mathrm{~g} \mathrm{~kg}^{-1}$ substrate DM via an in vitro gas technique, and Promkot and Wanapat [4], who supplemented sulfur at 1.5 and $4 \mathrm{~g} \mathrm{~kg}^{-1}$ of dietary DM in dairy cows.

Table 4. Effect of fresh cassava root (CR) and solid feed-block containing high sulfur (S-FB) on ruminal volatile fatty acid (VFA) and methane estimation $\left(\mathrm{CH}_{4}\right)$.

\begin{tabular}{|c|c|c|c|c|c|c|c|c|}
\hline \multirow{2}{*}{ Items } & \multicolumn{2}{|c|}{ CR-1 } & \multicolumn{2}{|c|}{ CR-1.5 } & \multirow{2}{*}{ SEM } & \multicolumn{3}{|c|}{$p$-Value } \\
\hline & S-FB-2 & S-FB-4 & S-FB-2 & S-FB-4 & & CR & S-FB & $C R * S-F B$ \\
\hline \multicolumn{9}{|l|}{ Total VFA, mM } \\
\hline 0 -h post-feeding & 101.5 & 104.0 & 102.5 & 104.0 & 1.38 & 0.90 & 0.12 & 0.86 \\
\hline 4-h post-feeding & 102.5 & 104.3 & 103.7 & 105.1 & 1.37 & 0.41 & 0.49 & 0.52 \\
\hline Mean & 102.0 & 104.2 & 103.1 & 104.6 & 1.35 & 0.60 & 0.63 & 0.42 \\
\hline \multicolumn{9}{|c|}{ Acetic acid (C2), mol $100 \mathrm{~mol}^{-1}$} \\
\hline 0-h post-feeding & 63.6 & 63.2 & 62.7 & 63.6 & 1.71 & 0.26 & 0.74 & 0.82 \\
\hline 4-h post-feeding & 64.4 & 65.3 & 63.3 & 62.3 & 1.53 & 0.22 & 0.69 & 0.75 \\
\hline Mean & 64.0 & 64.3 & 63.0 & 62.9 & 0.90 & 0.36 & 0.60 & 0.51 \\
\hline \multicolumn{9}{|c|}{ Propionic acid (C3), mol $100 \mathrm{~mol}^{-1}$} \\
\hline 0-h post-feeding & 21.7 & 22.2 & 23.2 & 23.6 & 1.12 & 0.97 & 0.12 & 0.86 \\
\hline 4-h post-feeding & 21.6 & 22.4 & 23.5 & 23.6 & 1.20 & 0.89 & 0.73 & 0.52 \\
\hline Mean & 21.7 & 22.3 & 23.4 & 23.6 & 0.77 & 0.65 & 0.43 & 0.99 \\
\hline \multicolumn{9}{|c|}{ Butyric acid (C4), mol $100 \mathrm{~mol}^{-1}$} \\
\hline 0-h post-feeding & 15.7 & 15.2 & 14.3 & 13.4 & 1.01 & 0.97 & 0.65 & 0.82 \\
\hline 4-h post-feeding & 15.8 & 12.3 & 13.2 & 14.1 & 1.52 & 0.47 & 0.60 & 0.77 \\
\hline Mean & 15.8 & 13.8 & 13.8 & 13.8 & 0.90 & 0.36 & 0.76 & 0.81 \\
\hline \multicolumn{9}{|l|}{$\mathrm{C} 2: \mathrm{C} 3$ ratio } \\
\hline 0-h post-feeding & 2.9 & 2.8 & 2.7 & 2.7 & 0.45 & 0.53 & 0.67 & 0.82 \\
\hline 4-h post-feeding & 3.0 & 2.9 & 2.7 & 2.6 & 0.36 & 0.27 & 0.75 & 0.73 \\
\hline Mean & 2.9 & 2.8 & 2.7 & 2.7 & 0.38 & 0.45 & 0.86 & 0.59 \\
\hline $\mathrm{C} 2+\mathrm{C} 4: \mathrm{C} 3$ ratio & 4.36 & 2.93 & 4.54 & 3.39 & 0.319 & 0.626 & 0.067 & 0.831 \\
\hline \multicolumn{9}{|c|}{ Methane $\left(\mathrm{CH}_{4}\right)^{\dagger}, \mathrm{g} \mathrm{day}^{-1}$} \\
\hline 0 -h post-feeding & 27.7 & 27.5 & 28.7 & 27.1 & 0.61 & 0.62 & 0.28 & 0.16 \\
\hline 4-h post-feeding & 27.2 & 26.4 & 27.5 & 26.6 & 1.34 & 0.80 & 0.56 & 0.98 \\
\hline Mean & 26.9 & 25.1 & 26.3 & 26.1 & 0.61 & 0.62 & 0.28 & 0.16 \\
\hline
\end{tabular}

CR-1 and CR-1.5 = fed CR at 10 and $15 \mathrm{~g} \mathrm{~kg}^{-1}$ BW, S-FB-2 and S-FB-4 = solid feed-block containing high sulfur at 20 and $40 \mathrm{~g} \mathrm{~kg}{ }^{-1}$, $\mathrm{SEM}=$ standard error of mean, $\mathrm{CR} * \mathrm{~S}-\mathrm{FB}=$ interaction effect between $\mathrm{CR}$ and $\mathrm{S}-\mathrm{FB} .{ }^{\dagger} \mathrm{CH}_{4}=(0.45 \times$ acetic acid $)-(0.275 \times$ propionic acid $)+$ $(0.40 \times$ butyric acid $)[14]$.

Table 5. Effect of fresh cassava root (CR) and solid feed-block containing high sulfur (S-FB) on thiocyanate $\left(\mathrm{SCN}^{-}\right)$, blood urea nitrogen $(\mathrm{BUN})$, thyroid hormones, and liver enzymes.

\begin{tabular}{|c|c|c|c|c|c|c|c|c|}
\hline \multirow{2}{*}{ Items } & \multicolumn{2}{|c|}{ CR-1 } & \multicolumn{2}{|c|}{ CR-1.5 } & \multirow{2}{*}{ SEM } & \multicolumn{3}{|c|}{$p$-Value } \\
\hline & S-FB-2 & S-FB-4 & S-FB-2 & S-FB-4 & & $\mathrm{CR}$ & S-FB & $C R^{*} S-F B$ \\
\hline $\begin{array}{c}\text { Serum } \mathrm{SCN}^{-} \\
\mu \mathrm{g} \mathrm{mL} \mathrm{mL}^{-1}\end{array}$ & 3.4 & 4.0 & 4.0 & 4.2 & 0.84 & 0.31 & 0.70 & 0.21 \\
\hline BUN, $\mathrm{mg} \mathrm{dL}^{-1}$ & 11.9 & 11.6 & 9.9 & 11.9 & 1.59 & 0.28 & 0.13 & 0.61 \\
\hline $\mathrm{T} 3, \mathrm{nmol} \mathrm{L}^{-1}$ & 0.7 & 0.6 & 0.6 & 0.5 .1 & 0.76 & 0.51 & 0.64 & 0.78 \\
\hline $\mathrm{T} 4, \mathrm{nmol} \mathrm{mL}^{-1}$ & 69.8 & 46.8 & 52.2 & 40.4 & 1.82 & 0.26 & 0.16 & 0.53 \\
\hline ALT, units $\mathrm{L}^{-1}$ & 15.3 & 14.8 & 15.8 & 14.5 & 1.09 & 0.91 & 0.43 & 0.73 \\
\hline AST, units $\mathrm{L}^{-1}$ & 40.5 & 45.8 & 47.5 & 41.8 & 2.85 & 0.60 & 0.93 & 0.07 \\
\hline
\end{tabular}

CR-1 and CR-1.5 = fed CR at 10 and $15 \mathrm{~g} \mathrm{~kg}^{-1}$ BW, S-FB-2 and S-FB-4 = solid feed-block containing high sulfur at 20 and $40 \mathrm{~g} \mathrm{~kg}^{-1}$, SEM = standard error of mean, $\mathrm{SCN}^{-}=$thiocyanate, $\mathrm{BUN}=$ blood urea nitrogen, $\mathrm{T} 3=$ triiodothyronine, $\mathrm{T} 4=$ thyroxine, $\mathrm{ALT}=$ alanine aminotransferase, $\mathrm{AST}=$ aspartate aminotransferase, $\mathrm{CR} * \mathrm{~S}-\mathrm{FB}=$ interaction effect between $\mathrm{CR}$ and S-FB.

\subsection{Blood Metabolites and Hormones}

The effects of $\mathrm{CR}$ and $\mathrm{S}-\mathrm{FB}$ on blood thiocyanate $\left(\mathrm{SCN}^{-}\right)$, blood urea nitrogen (BUN), thyroid hormones, and liver enzymes are presented in Table 5 . Interactive effects between $\mathrm{CR}$ and $\mathrm{S}-\mathrm{FB}$ on blood $\mathrm{SCN}^{-}, \mathrm{BUN}$, thyroid hormones (T3 and $\mathrm{T} 4$ ), and liver enzymes (ALT and AST) were not observed. CR-1 and CR-1.5 did not influence blood SCN ${ }^{-}, \mathrm{BUN}_{\text {, }}$ 
thyroid hormones, or liver enzymes (Table 5). The average $\mathrm{SCN}^{-}$concentrations between CR-1 and CR-1.5 were $3.7 \mu \mathrm{g} \mathrm{mL}^{-1}$ and $4.1 \mu \mathrm{g} \mathrm{mL}{ }^{-1}$, respectively. The lack of significant differences in $\mathrm{SCN}^{-}$after receiving CR-1 and CR-1.5 might be related to the insignificant amounts of CR and HCN intake (Table 2). Cherdthong et al. [2] fed a feed-block containing sulfur to beef cattle and found no effects on BUN; however, a concentration of blood $\mathrm{SCN}^{-}$ was observed, which could have been due to the significant intake of $\mathrm{CR}$ as reported by the authors. Promkot and Wanapat [4] found that cassava hay and foliage did not affect BUN concentration but significantly influenced blood $\mathrm{SCN}^{-}$concentration, a finding that could be due to the significant intake of $\mathrm{HCN}$ found as a result of cassava hay and foliage feeding. The enzymes rhodanese and $\beta$-mercaptopyruvate available in animal cells and microorganisms in ruminants can be partially attributed to this finding [28]. The rhodanese enzyme is a sulfurtransferase that accelerates the formation of $\mathrm{SCN}^{-}$from HCN. S-FB-2 and S-FB-4 did not influence blood SCN ${ }^{-}$, BUN, thyroid hormones, or liver enzymes (Table 5). It might be that S-FB did not influence the CR or HCN intake (Table 2), thus resulting in a lack of effects on blood $\mathrm{SCN}^{-}$. The blood $\mathrm{SCN}^{-}$concentrations between S-FB-2 and S-FB-4 were $3.7 \mu \mathrm{g} \mathrm{mL}^{-1}$ and $4.1 \mu \mathrm{g} \mathrm{mL}^{-1}$, respectively. Cherdthong et al. [2] found that a feed-block containing sulfur at 20 and $40 \mathrm{~g} \mathrm{~kg}^{-1}$ significantly affected the blood $\mathrm{SCN}^{-}$ concentration, noting that the effect of sulfur on blood $\mathrm{SCN}^{-}$might be influenced by $\mathrm{CR}$. Promkot and Wanapat [4] found that sulfur supplementation at 1.5 and $4 \mathrm{~g} \mathrm{~kg}^{-1}$ of dietary $\mathrm{DM}$ caused an increase in blood $\mathrm{SCN}^{-}$in dairy cows; that could mainly depend on cassava hay and foliage feeding since an interactive effect between sulfur and cassava sources on blood $\mathrm{SCN}^{-}$was observed.

\subsection{Milk Production and Composition}

The effects of $\mathrm{CR}$ and $\mathrm{S}-\mathrm{FB}$ on milk $\mathrm{SCN}^{-}$, milk yield, milk composition, and somatic cell count (SCC) are presented in Table 6. Interactive effects between CR and S-FB on milk $\mathrm{SCN}^{-}$, milk yield, fat-corrected milk (FCM), milk composition, and SCC were not found. CR-1 and CR-1.5 did not influence milk yield, FCM, milk SCN ${ }^{-}$, or milk composition, with the exception of fat content and SCC (Table 6). Increasing the CR from 10 to $15 \mathrm{~g} \mathrm{~kg}^{-1}$ BW caused a significant increase in milk fat concentration, while it caused a significant decrease in the SCC. The reason for the increase in the milk fat content after CR feeding was not clear. $\mathrm{C} 2$ and $\mathrm{C} 4$ production in the rumen are the main precursors of milk fat synthesis [1,2,8,29]; however, CR-1 and CR-1.5 did not affect the C2 and C4 concentrations in this study. This result was similar to the result of Mosavi et al. [30], who evaluated various starch sources in the diets of dairy cows that produced a significant effect on milk fat. Promkot and Wanapat [4] used cassava hay and foliage as a roughage source in dairy cows' diets and found no effect on milk yield and milk composition, which may have been due to the lower starch content in cassava hay and foliage than in CR. Increasing CR feeding led to a significant decrease in the SCC in milk, a finding that may have been due to the antimicrobial effect of $\mathrm{SCN}^{-}$. The lactoperoxidase-thiocyanate-hydrogen peroxide (LP) system has been established as a feasible method for the temporary preservation of raw milk. The activity of the LP system against Gram-negative isolates from milk was initially applied to the reduction of bacterial flora during milk refrigeration. The LP system can inhibit many bacterial species, including a diversity of milk-borne spoilage and pathogenic microorganisms [31]. Petlum et al. [32] found that supplementation of cassava foliage led to a decrease in SCC. S-FB-2 and S-FB-4 did not affect milk yield, FCM, milk composition, milk SCN ${ }^{-}$, or SCC (Table 6). The milk yields of S-FB-2 and S-FB-4 were $11.2 \mathrm{~kg} \mathrm{day}^{-1}$ and $11.5 \mathrm{~kg} \mathrm{day}^{-1}$, respectively. The lack of difference in milk yield might be related to the lack of effect of S-FB intake and digestibility of DM and OM (Table 2). The milk $\mathrm{SCN}^{-}$concentrations between S-FB-2 and S-FB-4 were $7.5 \mathrm{ppm}$ and $7.9 \mathrm{ppm}$, respectively. Promkot and Wanapat [4] found a significant increase in milk protein in dairy cows, but other parameters did not change. These authors addressed this finding as possibly being related to greater DM, NDF, and ADF digestibility and N retention that could be affected by sulfur supplementation. Supapong and Cherdthong [1] added sulfur at 10 and $20 \mathrm{~g} \mathrm{~kg}^{-1}$ 
into the FTMR for dairy cows and found that sulfur addition did not affect milk yield; however, milk fat, $\mathrm{SCN}^{-}$, and SCC were influenced by sulfur supplementation. Supapong and Cherdthong [1] stated that an increase in milk fat with sulfur supplementation was found because sulfur affected the $\mathrm{C} 2$ and $\mathrm{C} 4$ concentrations since they acted as substrates for milk fat synthesis, while the increase in milk $\mathrm{SCN}^{-}$might be related to the increase in blood $\mathrm{SCN}^{-}$, which may partition into milk.

Table 6. Effect of fresh cassava root (CR) and a solid feed-block containing high sulfur (S-FB) on milk yield and its composition in lactating dairy cows.

\begin{tabular}{|c|c|c|c|c|c|c|c|c|}
\hline \multirow{2}{*}{ Items } & \multicolumn{2}{|c|}{ CR-1 } & \multicolumn{2}{|c|}{ CR-1.5 } & \multirow{2}{*}{ SEM } & \multicolumn{3}{|c|}{$p$-Value } \\
\hline & S-FB-2 & S-FB-4 & S-FB-2 & S-FB-4 & & CR & S-FB & $C R^{*} S-F B$ \\
\hline Milk yield, kg day ${ }^{-1}$ & 11.0 & 11.3 & 11.4 & 11.8 & 0.48 & 0.90 & 0.92 & 0.81 \\
\hline $\begin{array}{l}\text { 3.5\% } \text { FCM }^{\dagger} \\
\text { kg day }^{-1}\end{array}$ & 11.3 & 11.5 & 11.8 & 12.4 & 0.61 & 0.81 & 0.49 & 0.23 \\
\hline Milk fat, $\mathrm{g} \mathrm{kg}^{-1}$ & 31 & 32 & 35 & 38 & 0.30 & 0.04 & 0.59 & 0.21 \\
\hline Protein, $\mathrm{g} \mathrm{kg}^{-1}$ & 34 & 36 & 35 & 34 & 0.14 & 0.49 & 0.93 & 0.23 \\
\hline Lactose, $\mathrm{g} \mathrm{kg}^{-1}$ & 44 & 43 & 45 & 43 & 0.08 & 0.49 & 0.30 & 0.64 \\
\hline Solid-not-fat, $\mathrm{g} \mathrm{kg}^{-1}$ & 73 & 85 & 71 & 82 & 0.87 & 0.78 & 0.21 & 0.92 \\
\hline Total solids, $\mathrm{g} \mathrm{kg}^{-1}$ & 115 & 128 & 122 & 125 & 0.50 & 0.27 & 0.88 & 0.20 \\
\hline $\mathrm{SCN}^{-}, \mathrm{ppm}$ & 7.1 & 7.3 & 8.0 & 8.6 & 1.14 & 0.28 & 0.79 & 0.61 \\
\hline $\mathrm{SCC}, \times 10^{3}$ cell $\mathrm{mL}^{-1}$ & 285.5 & 249.5 & 110.5 & 102.3 & 0.20 & 0.02 & 0.21 & 0.26 \\
\hline
\end{tabular}

CR-1 and CR-1.5 = fed CR at 10 and $15 \mathrm{~g} \mathrm{~kg}^{-1}$ BW, S-FB-2 and S-FB-4 $=$ solid feed-block containing high sulfur at 20 and $40 \mathrm{~g} \mathrm{~kg}^{-1}, \mathrm{SCN}^{-}=$thiocyanate, SEM = standard error of mean, $\mathrm{CR}{ }^{*} \mathrm{~S}-\mathrm{FB}=$ interaction effect between $\mathrm{CR}$ and S-FB. ${ }^{+}$FCM $=$Fat-corrected milk.

\section{Conclusions}

CR and S-FB had no interactive effect on feed intake, digestibility, blood metabolites milk yield, or milk composition. A $15 \mathrm{~g} \mathrm{~kg}^{-1} \mathrm{BW}, \mathrm{CR}$ produced a significantly greater milk fat concentration, while significantly lower SCC was found when compared with $10 \mathrm{~g} \mathrm{~kg}^{-1}$ BW of CR. The solid feed-block containing sulfur up to $40 \mathrm{~g} \mathrm{~kg}^{-1}$ presented significantly greater ADF digestibility when compared with solid feed-block containing sulfur up to $20 \mathrm{~g} \mathrm{~kg}^{-1}$.

Author Contributions: Planning and design of the study, G.D. and A.C.; sampling, G.D., A.C., and S.S.; sample analysis, G.D.; statistical analysis, G.D.; drafting manuscript, G.D., A.C., and S.S.; editing and finalizing manuscript, G.D., A.C., S.S., M.W., and S.P. All authors have read and agreed to the published version of the manuscript.

Funding: The authors express their most sincere gratitude to the Research Program on the Research and Development of Winged Bean Root Utilization as Ruminant Feed; the Increase Production Efficiency and Meat Quality of Native Beef and Buffalo Research Group; Research and Graduate Studies, Khon Kaen University (KKU). Thailand Research and Researcher for Industry (RRi- MSD60I0023) and Agricultural Research Development Agency (Public Organization- PRP6005020500) is gratefully acknowledged. Gamonmas Dagaew was granted by Animal Feed Inter Trade Co., Ltd and Thailand Science Research and Innovation (TSRI) through the RRi programme (contract grant PHD62I0021).

Institutional Review Board Statement: The study was conducted under approval procedure no. ACUC-KKU 45/2560 of Animal Ethics and Care issued by KKU (Date: 15 June 2017).

Informed Consent Statement: Not applicable.

Data Availability Statement: Not applicable.

Acknowledgments: Thanks to the Tropical Feed Resources Research and Development Center (TROFREC), Department of Animal Science, Faculty of Agriculture, KKU for the use of its research facilities.

Conflicts of Interest: The authors declare no conflict of interest. 


\section{References}

1. Supapong, C.; Cherdthong, A. Effect of sulfur concentrations in fermented total mixed rations containing fresh cassava root on rumen fermentation. Vet. Sci. 2020, 7, 98. [CrossRef]

2. Cherdthong, A.; Khonkhaeng, B.; Seankamsorn, A.; Supapong, C.; Wanapat, M.; Gunun, N.; Gunun, P.; Chanjula, P.; Polyorach, S. Effects of feeding fresh cassava root with high-sulfur feed block on feed utilization, rumen fermentation, and blood metabolites in Thai native cattle. Trop. Anim. Health Prod. 2018, 50, 1365-1371. [CrossRef]

3. Promkot, C.; Wanapat, M.; Wachirapakorn, C.; Navanukraw, C. Influence of sulfur on fresh cassava foliage and cassava hay incubated in rumen fluid of beef cattle. Asian-Australas. J. Anim. Sci. 2007, 20, 1424-1432. [CrossRef]

4. Promkot, C.; Wanapat, M. Effect of elemental sulfur supplementation on rumen environment parameters and utilization efficiency of fresh cassava foliage and cassava hay in dairy cattle. Asian-Australas. J. Anim. Sci. 2009, 22, 1366-1376. [CrossRef]

5. Supapong, C.; Cherdthong, A.; Wanapat, M.; Chanjula, P.; Uriyapongson, S. Effects of sulfur levels in fermented total containing fresh cassava root on feed utilization, rumen characteristics, microbial protein synthesis, and blood metabolites in Thai native beef cattle. Animals. 2019, 9, 261. [CrossRef] [PubMed]

6. Prachumchai, R.; Cherdthong, A.; Wanapat, M. Screening of cyanide-utilizing bacteria from rumen and in vitro evaluation of fresh cassava root utilization with pellet containing high sulfur diet. Vet. Sci. 2021, 8, 10. [CrossRef]

7. FAO. Feed supplementation block technology_Past, present and future. In Feed Supplementation Blocks-Urea-Molasses Multinutrient Blocks: Simple and Effective Feed Supplement Technology for Ruminant Agriculture; Makkar, H.P.S., Sánchez, M., Speedy, A.W., Eds.; Food and Agriculture Organization of the United Nations: Rome, Italy, 2007; pp. 1-12.

8. Cherdthong, A.; Wanapat, M.; Rakwongrit, D.; Khota, W.; Khantharin, S.; Tangmutthapattharakun, G.; Kang, S.; Foiklang, S.; Phesatcha, K. Supplementation effect with slow-release urea in feed blocks for Thai beef cattle-nitrogen utilization, blood biochemistry and hematology. Trop. Anim. Health Prod. 2014, 46, 293-298. [CrossRef]

9. Dagaew, G.; Cherdthong, A.; Wanapat, M.; Chanjula, P. In vitro rumen gas production kinetics, hydrocyanic acid concentration and fermentation characteristics of fresh cassava root and feed block sulfur concentration. Anim. Prod. Sci. 2020, 60, 659-664. [CrossRef]

10. Belyea, R.L.; Ricketts, R.E. Forages for Cattle: New Methods of Determining Energy Content and Evaluating Heat Damage. University of Missouri Extension. 1993. Available online: https:/ / extension.missouri.edu/publications/g3150 (accessed on 30 June 2021).

11. AOAC. Official Methods of Analysis, 19th ed.; Association of Official Analytical Chemists: Gaithersburg, MD, USA, 2012.

12. Van Soest, P.J.; Robertson, J.B.; Lewis, B.A. Methods for dietary fiber neutral detergent fiber and non-starch polysaccharides in relation to animal nutrition. J. Dairy Sci. 1991, 74, 3583-3597. [CrossRef]

13. Van Keulen, J.; Young, B.A. Evaluation of acid-insoluble ash as a natural marker in ruminant digestibility studies. J. Anim. Sci. 1997, 44, 282-287. [CrossRef]

14. AOAC. Official Methods of Analysis, 15th ed.; Association of Official Analytical Chemists: Gaithersburg, MD, USA, 1990.

15. Moss, A.R.; Jouany, J.P.; Newbold, J. Methane production by ruminants: Its contribution to global warming. Anim. Res. 2000, 49, 231-253. [CrossRef]

16. Galyean, M. Laboratory Procedures in Animal Nutrition Research; New Mexico State University: Las Cruces, NM, USA, 1989.

17. Crocker, C.L. Rapid determination of urea nitrogen in serum or plasma without deproteinization. Amer. J. Med. Technol. 1967, 33, 361-365.

18. Jacob, B.M.; Antony, K.E.; Sreekumar, B.; Haridas, M. Thiocyanate mediated antifungal and antibacterial property of goat milk lacto-peroxidase. Life Sci. 2000, 66, 2433-2439. [CrossRef]

19. Tukey, J.W. Comparing individual means in the analysis of variance. Biometrics. 1949, 5, 99-114. [CrossRef] [PubMed]

20. NRC. Nutrient Requirements of Dairy Cattle, 7th ed; The National Academies Press: Washington, DC, USA, 2001.

21. Wanapat, M.; Kang, K. Cassava chip (Manihot esculenta Crantz) as an energy source for ruminant feeding. Anim. Nutr. 2015, 1, 266-270. [CrossRef] [PubMed]

22. Uwituze, S.; Parsons, G.L.; Karges, K.K.; Gibson, M.L.; Hollis, L.C.; Higgins, J.J.; Drouillard, J.S. Effects of distillers grains with high sulfur concentration on ruminal fermentation and digestibility of finishing diets. J. Anim. Sci. 2011, 89, 2817-2828. [CrossRef]

23. Fang, H.; Liu, H. Effect of $\mathrm{pH}$ on hydrogen production from glucose by a mixed culture. Bioresour. Technol. 2002, 82, 87-93. [CrossRef]

24. Shah, A.M.; Ma, J.; Wang, Z.; Hu, R.; Wang, X.; Peng, Q.; Amevor, F.K.; Goswami, N. Production of hydrogen sulfide by fermentation in rumen and its impact on health and production of animals. Processes. 2020, 8, 1169. [CrossRef]

25. McSweeney, C.S.; Denman, S.E. Effect of sulfur supplements on cellulolytic rumen micro-organisms and microbial protein synthesis in cattle fed a high fibre diet. J. Appl. Microbiol. 2007, 103, 1757-1765. [CrossRef]

26. Slyter, L.L.; Chalupa, W.; Oltjen, R.R.; Weaver, J.M. Sulfur influences on rumen microorganisms in vitro and in sheep and calves. J. Anim. Sci. 1986, 63, 1949-1959. [CrossRef]

27. Boucher, S.E.; Ordway, R.S.; Whitehouse, N.L.; Lundy, F.P.; Kononoff, P.J.; Schwab, C.G. Effect of incremental urea supplementation of a conventional corn silage-based diet on ruminal ammonia concentration and synthesis of microbial protein. J. Dairy Sci. 2007, 90, 5619-5633. [CrossRef] [PubMed]

28. Frankenberg, L. Enzyme therapy in cyanide poisoning: Effect of rhodanese and sulfur compounds. Arch. Toxicol. 1980, 45, 315-323. [CrossRef] [PubMed] 
29. So, S.; Wanapat, M.; Cherdthong, A. Effect of sugarcane bagasse as industrial by-products treated with Lactobacillus casei TH14, cellulase and molasses on feed utilization, ruminal ecology and milk production of mid-lactating Holstein Friesian cows. J. Sci. Food Agri. 2021, 101, 4481-4489. [CrossRef]

30. Mosavi, G.H.R.; Fatahnia, F.; Mirzaei, A.H.R.; Mehrabi, A.A.; Darmani, K.H. Effect of dietary starch source on milk production and composition of lactating Holstein cows. S. Afr. J. Anim. Sci. 2012, 42, 201-209. [CrossRef]

31. Zapico, P.; Gaya, P.; Nuñez, M.; Medina, M. Activity of goat's milk lactoperoxidase system on Pseudomonas fluorescens and Escherichia coli at refrigeration temperatures. J. Food Prot. 1995, 58, 1136-1138. [CrossRef]

32. Petlum, A.; Surachai, B.; Werachai, T.; Kanawit, P.; Phanompon, W.; Anurak, P.; Ladda, P.; Manoch, K. Effect of ensiled cassava foliage supplementation on milk yield and milk quality of lactating dairy cows in smallholder farms. Khon Kaen Agric. J. 2012, 40, $114-117$. 